\title{
TEMPORAL TRENDS OF CLIMATE INDICES ASSOCIATED WITH PRECIPITATION AND AIR TEMPERATURE IN MINAS GERAIS, BRAZIL
}

\author{
OLIVEIRA, Alisson Souza de - alissonso@hotmail.com \\ Universidade Vale do Rio Verde/ UninCor
}

\author{
MELLO, Carlos Rogério de - crmello@deg.ufla.br \\ Universidade Federal de Lavras / UFLA
}

\author{
MARQUES, Rosângela Francisca de Paula Vitor - roeflorestal@hotmail.com \\ Universidade Vale do Rio Verde/ UninCor
}

\begin{abstract}
The objective of this study was to evaluate the trends of four climatic extremes indices related to minimum and maximum air temperatures and three related to precipitation in Minas Gerais state, Brazil, from 1961 to 2010. These indices were developed by the Expert Team on Climate Change Detection Monitoring and Indices (ETCCDMI) with the aim of subsidizing climate change on global, regional and local levels. Daily rainfall and temperature long-term series were obtained from the National Institute of Meteorology (INMET) for 47 municipalities, in different regions of the state. The analyzes were conducted considering the four seasons of the year based on the Mann-Kendall and linear regression tests. There was a significant trend towards change in the indices related to minimum (TNn; TNx) and maximum ( $T X n$; TXX) temperatures all over the state. Precipitation indices (R10mm, R20mm and SDII) have showed no significant changes. The increase in the TNn, TNx, TXn and TXX has been observed in all seasons, except for autumn, and the TNx index in the winter. Both minimum and maximum temperatures indices have showed increase in greatest part of Minas Gerais in the spring, evidencing an expressive heating in this season and a premature summer onset. In the autumn, there was a downward trend in all temperature indices, characterizing an anticipation of winter. In winter, there was an upward trend in the TNn index and downward of the TNx in almost the entire state, indicating a reduction in the frost occurrence possibility, especially in the South and Southeast regions. The highest rates were observed in the Mid-west and Northwest regions. For the TXX index, in the summer there were upward trends throughout the state, especially in the North. Thus, important consequences to the agriculture planning and zoning have taken place as well as a proliferation of arbovirus diseases, affecting the life quality of the population
\end{abstract}

KEYWORDS: Climate Trends, Global Warming, Climate Indicators, Tropical Region

TENDÊNCIA TEMPORAL EM ÍNDICES CLIMÁTICOS ASSOCIADOS À PRECIPITAÇÃO E TEMPERATURA DO AR NO ESTADO DE MINAS GERAIS

RESUMO: O objetivo deste estudo foi avaliar as tendências de quatro índices extremos climáticos relacionados às temperaturas mínima e máxima do ar e três relacionados à precipitação no estado de Minas Gerais, Brasil, de 1961 a 2010. Esses índices foram desenvolvidos pela equipe de especialistas em mudanças climáticas Expert Team on Climate Change Detection Monitoring and Indices (ETCCDMI) com o objetivo de avaliar as alterações climáticas nos níveis global, regional e local. Para tanto, foram utilizadas séries históricas obtidas junto ao Instituto Nacional de Meteorologia (INMET) para 47 municípios, em diferentes regiões do estado. As análises foram conduzidas na escala sazonal considerando as quatro estações do ano com base nos testes de Mann-Kendall e de regressão linear. Houve uma tendência significativa de mudança nos índices relacionados às temperaturas mínima $(T N n ; T N x)$ e máxima ( $T X n ; T X x)$ em todo o estado. Os índices de precipitação (R10mm, R20mm e SDII) não mostraram alterações significativas. O aumento do TNn, TNx, TXn e TXx foi observado em todas as estações, exceto no outono e no índice TNx no inverno. Os índices de temperatura mínima e 
máxima mostraram aumento na maior parte de Minas Gerais na primavera, evidenciando um aquecimento expressivo nesta temporada e um início prematuro do verão. No outono, houve uma tendência de queda em todos os índices de temperatura, caracterizando uma antecipação do inverno. No inverno, houve uma tendência ascendente no índice TNn e descendente do TNx em quase todo o estado, indicando uma redução na possibilidade de ocorrência de geadas, principalmente nas regiões Sul e Sudeste. As taxas mais altas foram observadas nas regiões Centro-Oeste e Noroeste. Para o índice TXx, no verão houve tendências de alta em todo o estado, principalmente no norte. Assim, ocorrerão importantes consequências para o planejamento e zoneamento agrícola, bem como a proliferação de doenças por arbovírus, afetando a qualidade de vida da população.

PALAVRAS-ChaVe: Tendências Climáticas, Aquecimento Global, Indicadores Climáticos, Região Tropical.

\section{TENDENCIA TEMPORAL EM LOS ÍNDICES CLIMÁTICOS ASSOCIADOS COM LA PRECIPITACIÓN Y LA TEMPERATURA DEL AIRES EM LE ESTADO DE MINAS GERAIS}

RESUMEN: El objetivo de este estudio fue evaluar las tendencias de cuatro índices climáticos extremos relacionados con las temperaturas mínimas y máximas del aire y tres relacionados con la precipitación en el estado de Minas Gerais, Brasil, de 1961 a 2010. Estos índices fueron desarrollados por el equipo de especialistas en cambio climático. Equipo de Expert Team on Climate Change Detection Monitoring and Indices (ETCCDMI) con el objetivo de evaluar el cambio climático a nivel global, regional y local. Para ello, se utilizaron series históricas obtenidas del Instituto Nacional de Meteorología (INMET) para 47 municipios, en diferentes regiones del estado. Los análisis se realizaron en una escala estacional considerando las cuatro estaciones del año basadas en las pruebas de regresión lineal y Mann-Kendall. Hubo una tendencia significativa de cambio en los índices relacionados con las temperaturas mínimas (TNn; TNx) y máximas (TXn; TXX) en todo el estado. Las tasas de precipitación (R10mm, R20mm y SDII) no mostraron cambios significativos. El aumento en TNn, TNx, TXn y TXx se observó en todas las estaciones, excepto en otoño y en el índice TNx en invierno. Los índices de temperatura mínima y máxima mostraron un aumento en la mayoría de Minas Gerais en la primavera, mostrando un calentamiento significativo esta temporada y un comienzo prematuro del verano. En el otoño, hubo una tendencia a la baja en todos los índices de temperatura, caracterizando una anticipación del invierno. En invierno, hubo una tendencia al alza en el índice TNn y una tendencia a la baja de TNx en casi todo el estado, lo que indica una reducción en la posibilidad de heladas, especialmente en las regiones del sur y sudeste. Las tasas más altas se observaron en las regiones del Medio Oeste y Noroeste. Para el índice TXx, en el verano hubo tendencias al alza en todo el estado, especialmente en el norte. Por lo tanto, habrá importantes consecuencias para la planificación agrícola y la zonificación, así como la proliferación de enfermedades causadas por arbovirus, que afectarán la calidad de vida de la población.

PALABRAS ClAVE: Tendencias Climáticas, Calentamiento Global, Indicadores Climáticos, Región Tropical.

\section{INTRODUCTION}

The Intergovernmental Panel on Climate Change (IPCC, 2014) released in its 5th Climate Assessment Report (AR5) that unprecedented global warming is a fact, and greenhouse gas (GHG) emissions are among the reasons. One way to minimize the consequences of global warming is to drastically reduce GHG emissions, otherwise the planet will reach the end of this century with an average temperature increase of up to $5.8^{\circ} \mathrm{C}$. Between 2000 and $2010, \mathrm{GHG}$ emissions grew faster than in the previous decade, mainly due to the increased 
use of coal for power generation. Today, the concentration of greenhouse gases in the atmosphere is the highest in 800,000 years (IPCC, 2014).

Climatologists have found that significant increases in global temperature have occurred in recent decades (Marcott et al., 2013). This phenomenon has caused changes in the Earth's climate, provoking a series of alterations in the environment that can generate diverse economic, social and environmental impacts (Lobell et al., 2011, Obregón and Marengo, 2007). Alexander et al. (2006) conducted a global study on climate alterations with rainfall series between 1901 and 2003 and did not observe significant alterations for the R10mm and R20mm indices. Regarding the SDII index, they observed significant alterations in only $14.6 \%$ of the study area. Stephenson et al. (2014) worked with extreme precipitation rates in the Caribbean region with rainfall series at 51 stations in the periods 1961 to 2010 and 1986 and 2010. The authors observed significant upward trends in the SDII index only in 3 of the 51 stations analyzed, with rates of $0.77 ; 1.03$ and $1.43 \mathrm{~mm}$ day-1 per decade. Several studies have shown different trends in climate change behavior in various regions of the world (Vargas et al., 2008; Martinez et al., 2012; Santos, et al., 2013; Sharna, et al., 2014; Omondi et al., 2014; Powell et al., 2015). The tropical regions have received little attention regarding impacts from climate change mainly in south hemisphere as the greatest concerns have been focused on temperate and polar regions in the north hemisphere.

According to the Fifth Assessment Report (AR5) of the IPCC (IPCC, 2013), Brazil's average temperature, in the worst scenario, may increase by $4.0^{\circ} \mathrm{C}$ by 2100 . Salviano et al. (2016) analyzed data from Brazil's spatially distributed precipitation and temperature data from the Climatic Research Unit (CRU) between 1961 and 2011. They found that precipitation did not present a significant trend in more than $70 \%$ of the Brazilian territory, in all months. However, in the western Amazon region, there was an upward trend in the rainy season (January to April) and a downward trend in the driest period (June to September). In the driest months, in the Northeastern region, mainly in the semi-arid region, and in the states of Middle-west Brazilian region, upward trends were found as well as in the coastal strip between Rio Grande do Sul and Rio de Janeiro. Santos et al. (2012), working with rainfall series between 1971 and 2007 at three stations located in the Manaus region, found significant results of an increase in several climatic extreme indices, including $\mathrm{R} 10 \mathrm{~mm}$ and R20mm, for two seasons. Still with this index, Santos (2014) working with precipitation series between 1980 and 2004 in an ecological reserve in the Federal District, did not observe a significant trend. Neves et al. (2016), studying 28 municipalities in the Paraná state, South Brazil, with maximum and minimum air temperature series, similar to the study by Ávila et al. (2014), in the period from 1980 to 2009, observed alterations in most of these stations, from reductions, with rates up to $-0.5^{\circ} \mathrm{C}$. Penereiro et al., 2017 working with series of maximum and minimum temperatures and temperatures and media in 243 locations distributed throughout the territory of Brazil, observing the absence of trends in rainfall stations. However, there is a high probability of an increase in minimum temperatures (34.16\% of localities), media $(35.39 \%$ of localities) and maximum (35.39\% of localities). The locations in temperatures concentrated in the North and Southeast regions, in the south of the Northeast region and in the north of the South region, particularly in the localities in the last decade of the last century and in the first decade of the last century, after 
an increase in the urban area, followed by deforestation and agricultural and industrial development. Pinheiro et al. (2013), evaluating the trends in precipitation series in southern Brazil, found a tendency towards increase in monthly and annual totals in 16 of the 18 rainfall stations evaluated in the Paraná state, with increases varying from $90.7 \mathrm{~mm}$ to $715.7 \mathrm{~mm}$. January showed an upward trend in all rainfall stations, with only Foz do Iguaçu station showing a reduction of $15.4 \mathrm{~mm}$. All stations in Santa Catarina had an upward trend, while in Rio Grande do Sul, three had an upward trend and two, a downward trend. Cordeiro et al. (2016) analyzing series of minimum, maximum and average air temperature in the State of Rio Grande do Sul (Brazilian subtropical region) observed a strong upward trend in the minimum air temperature. The authors attributed this behavior to a possible influence of the El Niño phenomenon, which has been more frequent and strong since 1980 (Wang et al. 2017), mainly in spring and early summer. According to the cited authors, in both spring and early summer have presented the greatest impact on the climate.

In this direction, the ETCCDI expert team (Expert Team on Climate Change Detection and Indices), supported by the Commission for Climatology (CCI) of the World Meteorological Organization (WMO) and by the Climate Variability and Predictability Project (CLIVAR), begun in 1995 under the World Climate Research Program, to develop a set of extreme indices that represent a common guideline for regional climate analysis derived from daily precipitation and air temperature data. A detailed description of these indices and their meanings can be found in Donat et al. (2013), Alexander et al. (2006) and in the CLIMDEX Website project (http://www.climdex.org). From these indices, studies on climate change have been widely used as a tool to assess and monitor changes in climate extremes around the world (Brown et al., 2010; Stephenson et al., 2014; Sharma et al., 2014; Kruger et al., 2013; Powell et al., 2015).

Although some work has already been carried out in the state of Minas Gerais (Ávila et al., 2014; Haddad et al. 2011; Minuzzi et al. 2010; Nunes et al. 2018; Natividade et. al., 2017), southeastern Brazil, on changes in climate behavior in the last 50 years, in none of these were studied the extreme weather indices. Thus, it is understood that the use of these indices will promote a substantial refinement of climate behavior in this state which is entirely located in tropical region of South America, over the past 50 years. Therefore, the objective of this study was to analyze the behavioral trend of extreme air temperature (minimum and maximum temperatures) and temperature indices in Minas Gerais state, southeastern Brazil.

\section{MATERIAL AND METHODS}

\section{PHYSIOGRAPHIC AND CLIMATIC CHARACTERISTICS OF THE MINAS GERAIS STATE, SOUTHEASTERN BRAZIL, AND AVAILABLE DATABASE}

To carried out this study, daily precipitation and minimum and maximum air temperatures data sets were used from 47 climatological stations belonging to the national network of surface meteorological observations of the National Institute of Meteorology (INMET), distributed throughout the territory of Minas Gerais, comprising the period between 1961 and 2010. The state was split into 
macro-regions as follows: South ( 8 municipalities, all under the influence of the Cwa and Cwb climate types - temperate climates due to the altitude); Southeast (4 municipalities, with predominance of Cwa climate); Central-East (13 municipalities; climates Cwa and Aw, with predominance of the latter); Triangle/Northwest region (8 municipalities, climate Aw - essentially tropical) and North (13 municipalities, climate Aw).

The Aw climate is a tropical savanna climate (transition zones between forests and meadows with predominant grass vegetation). The driest period of the year coincides with winter, the maximum precipitation observed for the driest month in this season is less than $60 \mathrm{~mm}$. The predominant vegetation in these areas is the shrub and raster. The Cwa climate is a humid temperate climate with a dry winter, with an average rainfall of less than $60 \mathrm{~mm}$ in at least one of the months of this season. Hot summer with average temperature of the hottest month over $22^{\circ} \mathrm{C}$. The $\mathrm{Cwb}$ climate is a humid temperate climate with dry winter, whose average precipitation is less than $60 \mathrm{~mm}$ in at least one of the months of this season. The summer is moderately hot, with an average temperature of the hottest month below $22^{\circ} \mathrm{C}$ and in at least four months, it is above $10^{\circ} \mathrm{C}$ (Sá Júnior et al.,2012). Details of the stations used and the periods analyzed are descripted in Table I.

Table I - INMET climatological stations used in the present study, including the identification code, station name/region, coordinates, altitude and length of the series studied.

\begin{tabular}{|c|c|c|c|c|c|c|}
\hline Climate & Code & Municipality/Region & $\begin{array}{c}\text { Latitude } \\
\text { (degrees) }\end{array}$ & $\begin{array}{l}\text { Longitude } \\
\text { (degrees) }\end{array}$ & $\begin{array}{l}\text { Altitude } \\
(\mathrm{m})\end{array}$ & Period \\
\hline Aw & 83442 & Araçuaí/N & $-16^{\circ} 50^{\prime}$ & $-42005^{\prime}$ & 289.0 & $1961-2010$ \\
\hline Cwa & 83582 & Bambuí/C-E & $-20003^{\prime}$ & $-46000^{\prime}$ & 661.3 & $1961-2010$ \\
\hline Cwb & 83689 & Barbacena/S & $-21^{\circ} 25^{\prime}$ & $-43046^{\prime}$ & 1126.0 & $1961-2010$ \\
\hline Aw/Cwa & 83587 & Belo Horizonte/C-E & $-19056^{\prime}$ & $-43056^{\prime}$ & 915.0 & $1961-2010$ \\
\hline Aw & 83533 & Bom Despacho/C-E & $-19044^{\prime}$ & $-45^{0} 15^{\prime}$ & 720.0 & $1981-2010$ \\
\hline Cwb & 83681 & Caldas/S & $-21^{\circ} 55^{\prime}$ & $-46^{\circ} 38^{\prime}$ & 1150.0 & $1961-2010$ \\
\hline Cwb & 83639 & Caparaó/SE & $-20051^{\prime}$ & $-41^{\circ} 54^{\prime}$ & 843.2 & $1973-2010$ \\
\hline Aw & 83514 & Capinópolis/T-NW & -20012 & $-49056^{\prime}$ & 620.0 & $1970-2010$ \\
\hline Cwa & 83592 & Caratinga/C-E & $-19044^{\prime}$ & $-42013^{\prime}$ & 609.6 & $1961-2010$ \\
\hline Aw & 83485 & Carbonita/N & $-17053^{\prime}$ & $-43000^{\prime}$ & 736.4 & $1981-2010$ \\
\hline Cwa & 83589 & $\begin{array}{c}\text { Conceição do Mato } \\
\text { Dentro/C-E }\end{array}$ & 'רם & 'ב130 & 652.0 & $1961-2010$ \\
\hline Cwa & 83037 & Coronel Pacheco/SE & $-21^{\circ} 54^{\prime}$ & $-43043^{\prime}$ & 411.0 & 1966-2009 \\
\hline Aw & 83536 & Curvelo/C-E & $-18^{\circ} 46^{\prime}$ & $-44^{\circ} 26^{\prime}$ & 670.0 & $1961-2010$ \\
\hline Cwb & 83538 & Diamantina/N & $-18^{\circ} 24^{\prime}$ & $-43038^{\prime}$ & 1296.0 & $1961-2010$ \\
\hline Cwa & 83635 & Divinópolis/C-E & $-20017^{\prime}$ & $-45^{\circ} 27^{\prime}$ & 670.0 & $1995-2010$ \\
\hline Aw & 83338 & Espinosa/N & $-15^{\circ} 31^{\prime}$ & $-42008^{\prime}$ & 569.0 & $1974-2010$ \\
\hline Aw & 83581 & Florestal/C-E & $-20^{\circ} 24^{\prime}$ & $-44^{\circ} 41^{\prime}$ & 748.8 & $1961-2002$ \\
\hline Aw & 83334 & Formoso/T-NW & $-15^{\circ} 33^{\prime}$ & $-46^{\circ} 25^{\prime}$ & 840.0 & $1977-2010$ \\
\hline Aw & 83574 & Frutal/T-NW & $-20^{\circ} 03^{\prime}$ & $-48^{\circ} 56^{\prime}$ & 543.8 & $1961-2010$ \\
\hline Cwa & 83632 & Ibirité/C-E & $-20001^{\prime}$ & $-44^{\circ} 05^{\prime}$ & 814.5 & $1961-2010$ \\
\hline Cwa & 83488 & Itamarandiba/N & $-18^{\circ} 24^{\prime}$ & $-42051^{\prime}$ & 1097.0 & $1962-2010$ \\
\hline Aw & 83521 & Ituiutaba/T-NW & $-18^{\circ} 58^{\prime}$ & $-49051^{\prime}$ & 560.0 & $1980-2010$ \\
\hline Aw & 83395 & Janaúba/N & $-15^{0} 47^{\prime}$ & $-43030^{\prime}$ & 516.0 & $1977-2010$ \\
\hline Aw & 83386 & Januária/N & $-15^{\circ} 27^{\prime}$ & $-44036^{\prime}$ & 473.7 & $1961-2010$ \\
\hline Cwa & 83591 & João Monlevade/C-E & $-19050^{\prime}$ & $-43011^{\prime}$ & 859.8 & $1961-2002$ \\
\hline Aw & 83481 & João Pinheiro/T-NW & $-17024^{\prime}$ & $-46^{\circ} 17^{\prime}$ & 760.0 & $1961-2010$ \\
\hline Cwa & 83692 & Juiz de Fora/SE & $-22016^{\prime}$ & $-43035^{\prime}$ & 939.9 & $1961-2010$ \\
\hline
\end{tabular}




\begin{tabular}{|c|c|c|c|c|c|c|}
\hline Aw & 83452 & Juramento/N & $-16047^{\prime}$ & $-43^{\circ} 43^{\prime}$ & 650.0 & $1987-2010$ \\
\hline Cwa & 83687 & Lavras/S & $-21045^{\prime}$ & $-45^{\circ} 00^{\prime}$ & 918.8 & $1961-2010$ \\
\hline Cwa & 83683 & Machado/S & $-21040^{\prime}$ & $-45^{\circ} 55^{\prime}$ & 873.3 & $1961-2010$ \\
\hline Cwb & 83015 & Maria da Fé/S & $-22030^{\prime}$ & $-45^{\circ} 38^{\prime}$ & 1276.3 & $1976-2010$ \\
\hline Aw & 83389 & Mocambinho/N & $-15^{\circ} 08^{\prime}$ & $-44^{\circ} 01^{\prime}$ & 452.0 & $1976-2010$ \\
\hline Aw & 83388 & Monte Azul/N & $-15^{0} 08^{\prime}$ & $-42045^{\prime}$ & 603.6 & $1974-2010$ \\
\hline Aw & 83437 & Montes Claros/N & $-16^{0} 41^{\prime}$ & $-43^{\circ} 50^{\prime}$ & 646.3 & $1961-2010$ \\
\hline Cwa & 83637 & Oliveira/C-E & $-20041^{\prime}$ & $-44049^{\prime}$ & 966.5 & $1962-2010$ \\
\hline Aw & 83479 & Paracatu/T-NW & $-17023^{\prime}$ & $-46^{\circ} 53^{\prime}$ & 712.0 & $1973-2010$ \\
\hline Cwb & 83737 & Passa Quatro/S & $-22038^{\prime}$ & $-44^{0} 58^{\prime}$ & 920.0 & $1961-2010$ \\
\hline Aw & 83531 & Patos de Minas/T-NW & $-18^{\circ} 51^{\prime}$ & $-46^{\circ} 43^{\prime}$ & 940.3 & 1961-2010 \\
\hline Aw & 83393 & Pedra Azul/N & $-16001^{\prime}$ & $-41^{\circ} 28^{\prime}$ & 648.0 & $1972-2010$ \\
\hline Aw & 83570 & Pompeu/C-E & $-19021^{\prime}$ & $-45^{\circ} 00^{\prime}$ & 690.9 & $1973-2010$ \\
\hline Aw & 83441 & Salinas/N & $-16^{0} 16^{\prime}$ & $-42030^{\prime}$ & 471.3 & $1961-2010$ \\
\hline Cwb & 83736 & São Lourenço/S & $-22010^{\prime}$ & $-45^{\circ} 01^{\prime}$ & 953.2 & $1961-2010$ \\
\hline Cwa & 83631 & $\begin{array}{c}\text { São Sebastião do } \\
\text { Paraíso/S }\end{array}$ & $-20^{\circ} 55^{\prime}$ & $-47011^{\prime}$ & 820.0 & $1961-2010$ \\
\hline Aw & 83586 & Sete Lagoas/C-E & $-19028^{\prime}$ & $-44^{\circ} 25^{\prime}$ & 732.0 & $1961-2010$ \\
\hline Aw & 83577 & Uberaba/T-NW & $-19044^{\prime}$ & $-47057^{\prime}$ & 737.0 & $1961-2010$ \\
\hline Aw & 83428 & Unaí/T-NW & $-16^{\circ} 22^{\prime}$ & $-46055^{\prime}$ & 460.0 & $1978-2010$ \\
\hline Cwa & 83642 & Viçosa/SE & $-20045^{\prime}$ & $-42^{\circ} 51^{\prime}$ & 689.7 & 1961-2010 \\
\hline
\end{tabular}

Source: INMET; $\mathrm{S}=$ South; SE = Southeast; T-NW: Triangle-Northwest; C-E: Centraleast; $\mathrm{N}=$ North.

The State of Minas Gerais is in the Southeast region of Brazil, with an area of $586,521.2 \mathrm{~km}^{2}$, which corresponds to $7 \%$ of the national territory, being entirely inserted in the tropical latitude strip in South America. It has the 2nd largest population in the country and the 3rd largest Gross Domestic Product. Minas Gerais is the world's largest coffee producer and exporter, as well as being involved in other relevant economic activities such as dairy farming, grains and strong industrial activity, especially base industries, being the largest producer of steel in Brazil.

Minas Gerais has its relief is characterized by the existence of plateaus with escarpments, notably in the Mantiqueira Range, which takes place in part of the East, South and Southeast regions of the State, and Espinhaço Range, in the transition from the Center to the North. Most of the territory of Minas Gerais is at an altitude greater than 600 meters, with the Pico da Bandeira, the highest point at 2,890 $\mathrm{m}$ high, located in the eastern region.

Although to be in entirely inserted in the tropical region, due to its relief characteristics, Minas Gerais presents different climate types, which varying from semi-arid, in the north, to temperate in the mountains in south and southeast regions. Sá Júnior et al. (2012) studied these climates and their respective characterization and found out three climatic groups ( $A, B$ and $C$ ) and five classes (Am, Aw, BSh, Cwa and Cwb), following Köppen's climatic classification procedure. The Aw climatic class is the most representative covering an area about $67 \%$, followed by Cwa $(21 \%)$, Cwb (11\%) and the climatic classes Am and BSh with an area of less than $1 \%$ (Figure I).

The vegetation cover of Minas Gerais consists mainly of three main biomes: Cerrado, located in the Central and Triangle/Northwest region, occupying $57 \%$ of the area; Atlantic Forest, located in the east, south and southeast regions, corresponding to $41 \%$ of the area; and the Caatinga, 
restricted to the north, occupying about $2 \%$ of the territory of Minas Gerais (Scolforo et al. 2016).

\section{EXTREME CLIMATE INDICES}

The indices of extreme climatic events evaluated along with their definitions according to the "Expert Team on Climate Change Detection Monitoring and Indices" (ETCCDMI), are presented in Table II.

Table II - Definition of extreme weather event indices based on precipitation and air temperature data.

\begin{tabular}{|c|c|c|c|}
\hline Index & Identifier Name & Definition & Unit \\
\hline SDII & Daily simple intensity index & $\begin{array}{c}\text { Index of daily simple } \\
\text { precipitation intensity, obtained } \\
\text { by total precipitation divided by } \\
\text { the number of rainy days ( }>1.0 \\
\mathrm{~mm} \text { ) in the analyzed period. }\end{array}$ & $\mathrm{mm}$ \\
\hline R10mm & $\begin{array}{c}\text { Precipitation greater than } \\
\text { or equal to } 10 \mathrm{~mm}\end{array}$ & $\begin{array}{c}\text { Number of days in a year with } \\
\text { precipitation } \geq 10 \mathrm{~mm}\end{array}$ & $\mathrm{~mm}$ \\
\hline R20mm & $\begin{array}{c}\text { Precipitation greater than } \\
\text { or equal to } 20 \mathrm{~mm}\end{array}$ & $\begin{array}{c}\text { Number of days in a year with } \\
\text { precipitation } \geq 20 \mathrm{~mm}\end{array}$ & $\mathrm{~mm}$ \\
\hline TNn & $\begin{array}{l}\text { Lowest minimum } \\
\text { temperature }\end{array}$ & $\begin{array}{c}\text { Lowest minimum daily } \\
\text { temperature for the analyzed } \\
\text { period }\end{array}$ & ${ }^{\circ} \mathrm{C}$ \\
\hline TNx & $\begin{array}{l}\text { Highest minimum } \\
\text { temperature }\end{array}$ & $\begin{array}{l}\text { Highest minimum daily } \\
\text { temperature for the analyzed } \\
\text { period }\end{array}$ & ${ }^{\circ} \mathrm{C}$ \\
\hline TXn & $\begin{array}{l}\text { Lowest maximum } \\
\text { temperature }\end{array}$ & $\begin{array}{c}\text { Lowest maximum daily } \\
\text { temperature for the analyzed } \\
\text { period }\end{array}$ & ${ }^{\circ} \mathrm{C}$ \\
\hline $\mathbf{T X X}$ & $\begin{array}{l}\text { Highest maximum } \\
\text { temperature }\end{array}$ & $\begin{array}{c}\text { Highest maximum daily } \\
\text { temperature for the analyzed } \\
\text { period }\end{array}$ & ${ }^{\circ} \mathrm{C}$ \\
\hline
\end{tabular}

The calculation of the indices was performed using Excel software spreadsheets programmed in the Visual Basic for Applications (VBA) language. For the calculation of the SDII index, the period between the months of December and March was considered for all evaluated years. Due to the lack of data and the existence of gaps in some historical series, to obtain the other indices, we used years that presented a maximum of 65 days with failure. In addition, an analysis was performed on each data series to check for discrepancies when compared to the values observed at neighboring stations or in the data series itself. When these values were observed, the series was discarded. For the calculation of the precipitation indices $\mathrm{R} 10 \mathrm{~mm}$ and $\mathrm{R} 20 \mathrm{~mm}$, the period between January and December was considered for all years. The indices associated with the maximum (TXn and TXX) and minimum (TNn and TNx) temperatures were performed on a seasonal scale, where data series were monitored with the months of December, January and February (summer); March, April and May (autumn); June, July and August (winter); September, October and November (summer). 


\section{MANN-KENDALL NON-PARAMETRIC TEST AND REGRESSION ANALYSIS}

The Mann-Kendall test (Mann, 1945; Kendall, 1975) is a non-parametric statistical test applied to verify if a give data series presents a statistically significant temporal trend. Because it is a non-parametric test, it is not necessary that the data series to be normally distributed (Yue et al., 2002). Moreover, this method is little influenced by abrupt changes or nonhomogeneous series (Zhang et al., 2009). However, the method requires that the data are independent and homogeneous (Neeti and Eastman, 2011). Mann (1945) proposed for null hypothesis, HO, that the series originating from a population where the random variables are independent and equally distributed shows no trend. The alternative hypothesis, $\mathrm{H1}$, is that the data follow a monotonic trend in time. Under $\mathrm{HO}$, the application of the Mann-Kendall statistical test follows the following sequence of equations:

$$
S=\sum_{i=1}^{n-1} \sum_{j=i+1}^{n} \operatorname{sgn}\left(x_{j}-x_{i}\right)
$$

in which,

$$
\operatorname{sgn}\left(x_{j}-x_{i}\right)=\left\{\begin{array}{c}
+1 ; \text { se } x_{j} \geq x_{i} \\
0 ; \text { se } x_{j}=x_{i} \\
-1 ; \text { se } x_{j}<x_{i}
\end{array}\right\}
$$

Kendall (1975) shows that $S$ is normally distributed, and that the mean and variance of $S$, for a situation in which there can be equal values for the values of $x$, are calculated by the equations below:

$$
\begin{aligned}
& E\left[S_{i}\right]=0 \\
& \operatorname{Var}(s)=\frac{n(n-1)(2 n+5)-\sum_{j=1}^{p} t_{j}\left(t_{j}-1\right)\left(2 t_{j}+5\right)}{18}
\end{aligned}
$$

Considering equation (4), a positive value of $\mathrm{S}$ means an upward trend in. On the other hand, a negative value of $S$ means a downward trend. Knowing that $S$ is normally distributed and has mean zero and variance given by equation (5), one can verify whether the upward or downward trend is significantly different from zero. If $\mathrm{S}$ is significantly different from zero, $\mathrm{H}_{0}$ can be rejected for a certain level of significance pointing to the existence of a trend.

Mann (1945) and Kendall (1975) have shown that even for low values of $\mathrm{n}$, a normal distribution can be assumed as long as the value of the $\mathrm{Z}$ statistic is given by: 


$$
Z=\left\{\begin{array}{cc}
\frac{S-1}{(\operatorname{Var}(S))^{\frac{1}{2}}} & \text { se } S>0 \\
0 & \text { se } S=0 \\
\frac{S+1}{(\operatorname{Var}(S))^{\frac{1}{2}}} & \text { se } S<0
\end{array}\right.
$$

As it is a bilateral test for trend, $\mathrm{H}_{0}$ should be accepted if $Z \leq Z \frac{\alpha}{2}$, where $F_{N}\left(\frac{Z_{\alpha}}{2}\right)=\frac{\alpha}{2}$, significance level of the test.

The rate at which significant climate alteration occurred was estimated by the use of Regression Analysis by means of the angular significance of a line fitted to the data analyzed. To do so, the determination of the confidence interval of the coefficient is then calculated; if this interval does not include the zero value, the trend is significant. The regression coefficient significance test was performed using Student's t-test (Wilks, 1995), considering $5 \%$ of confidence level to compare with the tabulated critical value (bilateral test), with $\mathrm{n}-2$ degrees of freedom. If the value of $t$ calculated is higher than that tabulated, the null hypothesis is rejected, and the alternative one is accepted, which, in this case, is defined as the existence of a trend. Regression analysis was also used to estimate the increase or decrease when there was a trend, either upward or downward.

\section{RESULTS AND DISCUSSION}

\section{TREND IN THE EXTREME PRECIPITATION INDICES STUDIED FOR THE STATE OF MINAS GERAIS IN THE LAST 50 YEARS}

For the R10mm index, which is defined as the number of days in a year with precipitation equal to or greater than $10 \mathrm{~mm}$, from 47 stations (municipalities) analyzed, only $3(6.38 \%)$ presented a significant trend. In two of these stations (Frutal and Uberaba, both in the Triangle/Northwest region) significant trends were identified in this index, with rates of 4.77 and 3.43 days per decade, respectively, meaning an increase in the number of the rainy days. The station of Oliveira (Central region) showed a significant downward trend in this index, with a rate of -2.01 days per decade, being the only case observed in all over state (Figure Ia).

Regarding the R20mm index, significant trends were identified in a larger number of stations (7), however, corresponding to only $18.91 \%$ of the State. In these, 5 showed an upward trend of up to 4.07 days per decade (most in the Triangle/Northwest region) and in 2 (Lavras - South; Oliveira - Center) it was observed a downward trend of around -1.6 day per decade (Figure Ib). For both indices, it was observed that in the last 50 years there was practically no significant alteration for extreme precipitation events in Minas Gerais state.

For the simple index of daily precipitation intensity (SDII), significant upward trends were identified in only $5(10.64 \%)$ of the 47 stations analyzed, with rates up to $2.18 \mathrm{~mm}$ day-1 decade-1 and without a defined spatial trend 
(of those that are significant there is no dominance of a specific region). As in the other indices, only the municipality of Oliveira presented a significant downward trend of this index with a rate of $-2.54 \mathrm{~mm}$ day- ${ }^{1}$ per decade (Figure Ic).

Thus, based on the results presented in Figure I, no alteration pattern is seen in the three extreme precipitation indices, since these alterations occurred only in some isolated stations (municipalities). Although some of the municipalities evaluated presented significant trends, mainly upward, and in the Central and Triangle/Northwest regions, in general, this behavior was not verified for most of the Minas Gerais state. In the municipalities where this increase in the indices has been observed, this behavior may be associated with specific microclimates caused either by urbanization or by orographic effects, since Minas Gerais is characterized by mountains, very steep slopes, forming valleys and plateaus that influence the local dynamics of air mass movements (Mello et al., 2015). These effects notoriously affect the occurrence of convective rainfall events and orographic effects, which both present high spatial variability and are more linked to the extreme precipitation indices.
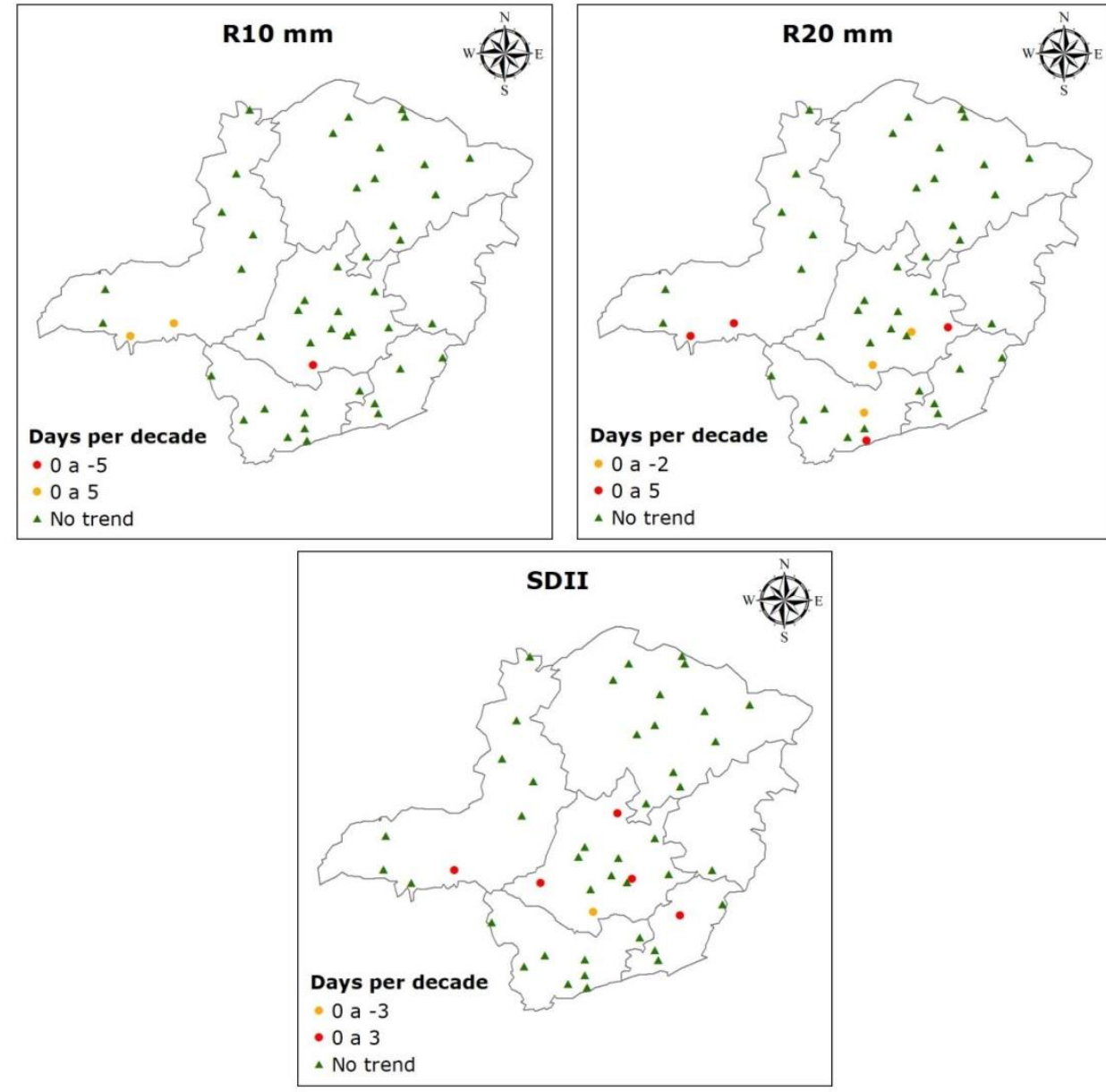

Figure I - Spatial distribution of extreme climatic precipitation trend indices (R10 $\mathrm{mm}$, R20 mm and SDII) for Minas Gerais state, Brazil, from 1961 to 2010. 


\section{MINIMUM AIR TEMPERATURE TREND IN MINAS GERAIS STATE IN THE LAST 50 YEARS}

The following results are related to the extreme indices of minimum temperature (TNn - the lowest value of daily minimum temperature, TNx - the highest value of daily minimum temperature) and average minimum air temperature for each season of the year, in Minas Gerais state, southeast Brazil.

In the spring, the TNn index (Figure IIa), 41 municipalities (87.2\% of all the stations) presented a significant upward trend with rates of up to $1.50^{\circ} \mathrm{C}$ per decade, being more evident in the Central and North regions. Only the station of Carbonita (northern region) presented a downward trend, with rate of $-0.89^{\circ} \mathrm{C}$ per decade. Another 7 stations did not show a significant trend towards alteration of this index, most of them in the Triangle/Northwest region (Figure IIa). Regarding the TNx index (Figure IIb), 34 (73.4\% of all the stations) showed a significant upward trend with rates between 0.10 and $0.67^{\circ} \mathrm{C}$ per decade, which were observed in all regions of Minas Gerais. However, in the same way as the TNn, the highest number of municipalities are concentrated in the Central and North regions, the majority with rates lower than $0.5^{\circ} \mathrm{C}$ per decade, meaning less impressive increases than those observed for the TNn index, for which mostly presented rates between 0.5 and $1.00 \mathrm{C} /$ decade. It is also interesting to note that 4 stations presented a downward trend in this index (TNx) up to -1oC/decade (Machado - South, Curvelo - North, Paracatu Triangle/Northwest, and Januária - North).

The summer analysis (Figure IIc) allowed us to evaluate that only $40.4 \%$ of the municipalities presented a significant upward trend in the TNn index, with rates between $0.06^{\circ} \mathrm{C}$ and $0.92^{\circ} \mathrm{C}$ per decade. In the other municipalities (59.6\%), no significant trends were observed. For the TNx index (Figure 3d), only $17.0 \%$ of the municipalities presented a significant upward trend, with predominance in the Center and South regions, with rates up to $1.00 \mathrm{C} / \mathrm{dec}$ de. In both regions, we can highlight the intense urbanization in the analyzed period which in turn can explain the possible causes for the increase in extremes of maximums in the summer. In another 7 municipalities, there was a significant downward trend in this index, with rates of up to $-1.0^{\circ} \mathrm{C}$ per decade, respectively, especially in municipalities whose meteorological stations are located at an altitude greater than $900 \mathrm{~m}$ in South, North and Central-East regions. The other 33 municipalities did not present a significant trend in the TNx index (Figure IId). Both indices have a significant impact on summer conditions and although summer extremes were expected to increase due to climate change and urbanization of the cities, this was not observed in the present study for Minas Gerais state. In general, the State of Minas Gerais has not experienced extreme maximum summer temperatures, and in cases where this has occurred (only $17 \%$ of municipalities), there is an association with the more intense urbanization conditions, such as in the metropolitan region of Belo Horizonte, a third Brazilian metropolitan with more than two million habitants.

Analyzing the autumn (Figure IIe), $78.7 \%$ of the municipalities in Minas Gerais presented a significant downward trend in the TNn index, with values up to $-2.00 \mathrm{C} /$ decade, however, with a predominance of rates between -0.5 and $1.00 \mathrm{C} /$ decade, in all over the state. With respect to the TNx index (Figure IIf), $82.9 \%$ of the municipalities presented a significant downward trend, with rates 
up to $-1.5^{\circ} \mathrm{C}$ per decade, however, with predominance of rates up to $0.5^{\circ} \mathrm{C} /$ decade.

In winter, 40 municipalities $(85.1 \%)$ presented a significant upward trend in the TNn index (Figure IIg), with rates lower than $-0.50 \mathrm{C} /$ decade. However, significant changes were observed throughout the State, with the highest rates in the Triangle/Northwest region. It is important to note that 7 municipalities did not present a significant trend and only 1 with a downward trend of $-0.470 \mathrm{C}$ (Curvelo - Center region). For the TNx index (Figure IIh), the dominance was of municipalities (31) that showed a significant downward trend with a predominance of rates of up to $-0.50^{\circ} \mathrm{C}$ per decade. There was a significant trend towards index increase in only 6 municipalities, with rates up to $0.68^{\circ} \mathrm{C}$ per decade.

Combining the two minimum temperature extreme indices, it is possible to verify that the autumn has been cooler in the last 50 years in Minas Gerais state, southeastern Brazil, showing an advance of the winter conditions, indicating a reduction of the minimum air temperatures, and indeed, cooler nights in this period. Therefore, a shortening of the winter period in its natural condition has been observed. It is important to point out that the autumn and spring are transition seasons and usually they present the greatest uncertainties in terms of forecast and climatological behavior in the tropical latitude range, and may present important alternation from year to year. 

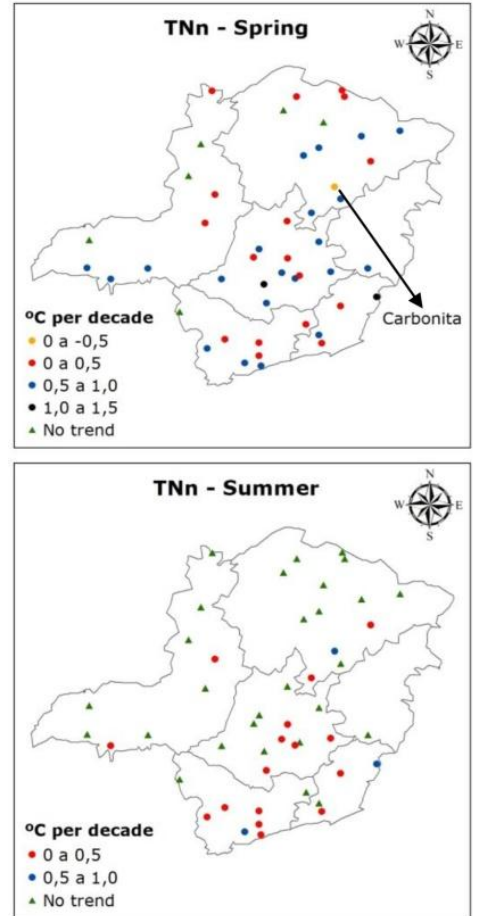

c)
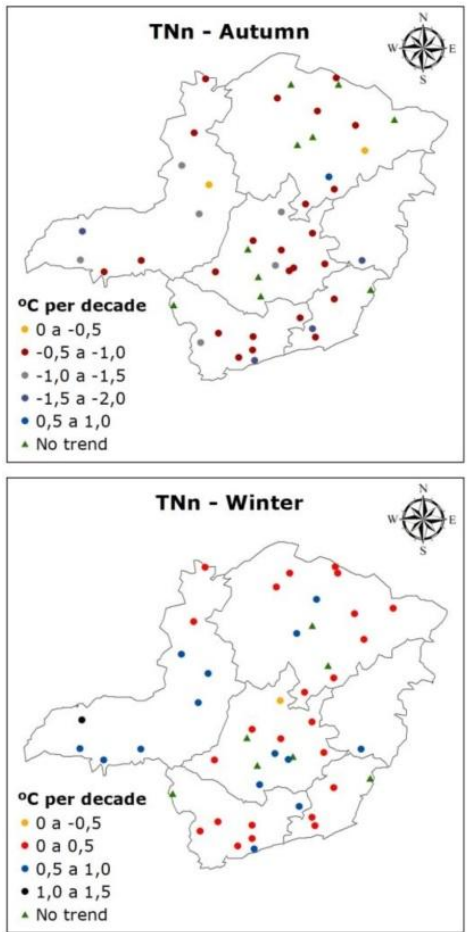

a)

g)

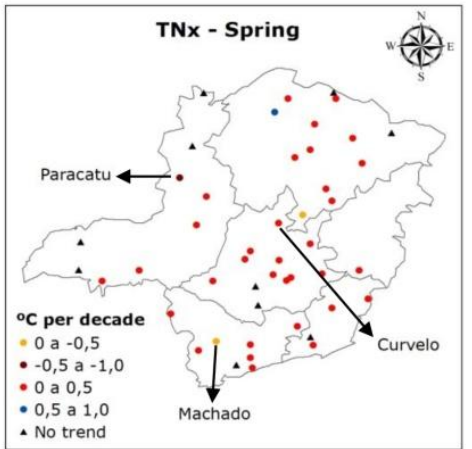

b)

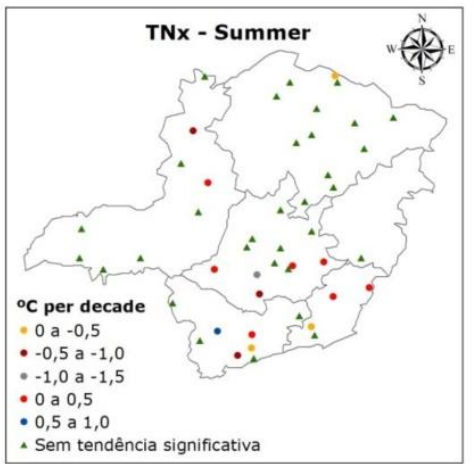

d)
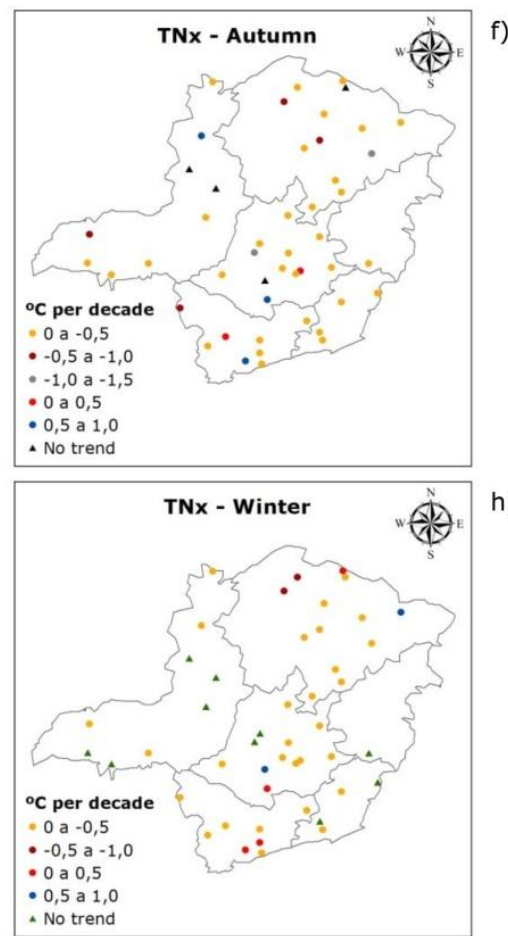

h)

Figure II - Spatial distribution of extreme climatic minimum air temperature trend indices for Minas Gerais state during the Spring (a, b), Summer (c, d), Autumn (e, f) and Winter $(\mathrm{g}, \mathrm{h})$, for the period 1961 to 2010 .

Also, specifically analyzing winter, $85.1 \%$ of the municipalities presented a significant upward TNn index trend, indicating an increase in the minimum 
temperature of the daily minimums in this season. This behavior is reflected in less cold nights and a decrease in the occurrence of frost events in the South and Southeastern regions of Minas Gerais. However, considering the TNx index, $69.5 \%$ of the municipalities evaluated showed a significant downward trend in the values of this index, i.e., there is a downward trend in the daily thermal amplitude in this period of the year. This aspect may impair the productivity of winter crops which require a minimum number of cold hours for their full development, such as winter wheat and fruit trees, both grown in the South and Southeastern regions of Minas Gerais.

\section{MAXIMUM AIR TEMPERATURE TREND IN MINAS GERAIS STATE IN THE LAST 50 YEARS}

Regarding the extreme indices related to the maximum temperature, significant trends were observed in all the seasons of the year. Considering the TXn index in the spring (Figure IIIa), $36.1 \%$ of the municipalities showed a significant upward trend with rates between 0.15 and $0.49^{\circ} \mathrm{C}$ per decade. The highest rates occurred in the South, Southeast and Triangle/ Northwest regions. In 11 municipalities, there was a significant downward trend up to $-1.0^{\circ} \mathrm{C}$, mostly in the North. The other municipalities $(40.4 \%)$ did not present a significant trend of this indicator in the spring. Based on the TXx index, only 9 (19.1\%) municipalities showed a significant downward trend with rates between -0.12 and $-0.61^{\circ} \mathrm{C}$ per decade. Spatially (Figure IIIb), there was no significant change in this index in Minas Gerais state, since 37 municipalities did not show a statistically significant trend. Based on the indices associated with the minimum and maximum temperatures, it is observed that the spring has been hotter in the last 50 years, especially regarding the minimum temperatures, although, in the maximums this change did not affect most the state.

In summer, the TXn index (Figure IIIc) showed a significant trend in most of Minas Gerais (78.7\% of municipalities), and in some cases this increase was up to $1.00 \mathrm{C} /$ decade. For the TXx index, significant upward trends were identified in only $17.0 \%$ of the municipalities, with rates between 0.09 and $0.28^{\circ} \mathrm{C}$ per decade. It is important to note that the municipality of Maria da Fé (southern region) presented a downward trend in this index at a rate of $-0.44^{\circ} \mathrm{C}$ per decade. However, most municipalities (80.8\%) did not present significant upward trends in the extreme maximum summer temperatures (Figure IIId). Thus, analyzing the behavior of the extreme minimum and maximum indices for the summer, it is observed that little significant alteration occurred with these temperatures in Minas Gerais state in the last 50 years.

In the autumn, $68.0 \%$ of the municipalities presented a significant downward trend in the TXn index (Figure IIIe), with rates up to $-0.92^{\circ} \mathrm{C}$ per decade, especially in southern region. The other municipalities did not present a significant trend of this index in the autumn. For the TXx index (Figure IIIf), significant downward trends were identified in $80.8 \%$ of municipalities, the great majority with rates of up to $-0.5^{\circ} \mathrm{C}$ per decade. In this season, there is also a general downward trend in the indices associated with extremes of maximum temperature in all regions of Minas Gerais, reinforcing the earlier observation of the cooler autumn trend described above based on the extreme indices of minimum temperatures. 
In winter, most of Minas Gerais state (93.6\% of municipalities) showed a significant upward trend in the TXn index (Figure IIIg), meaning an increase of extreme maximums of up to $1.0^{\circ} \mathrm{C}$ per decade. For the TXX, only $31.9 \%$ of the municipalities showed a significant upward trend, most of them less than $0.5^{\circ} \mathrm{C}$ per decade and concentrated in the South, Center and Triangle/Northwest regions. It is important to note that in $17.0 \%$ of the municipalities, significant downward trends were identified up to $-0.5^{\circ} \mathrm{C}$ per decade and that in $51.0 \%$ of the municipalities no significant trends were identified (Figure IIIh). These results reinforce the previous comments on the increase of extreme maximum temperatures in the State of Minas Gerais during the winter, especially based on the TNn and TXn indices. 

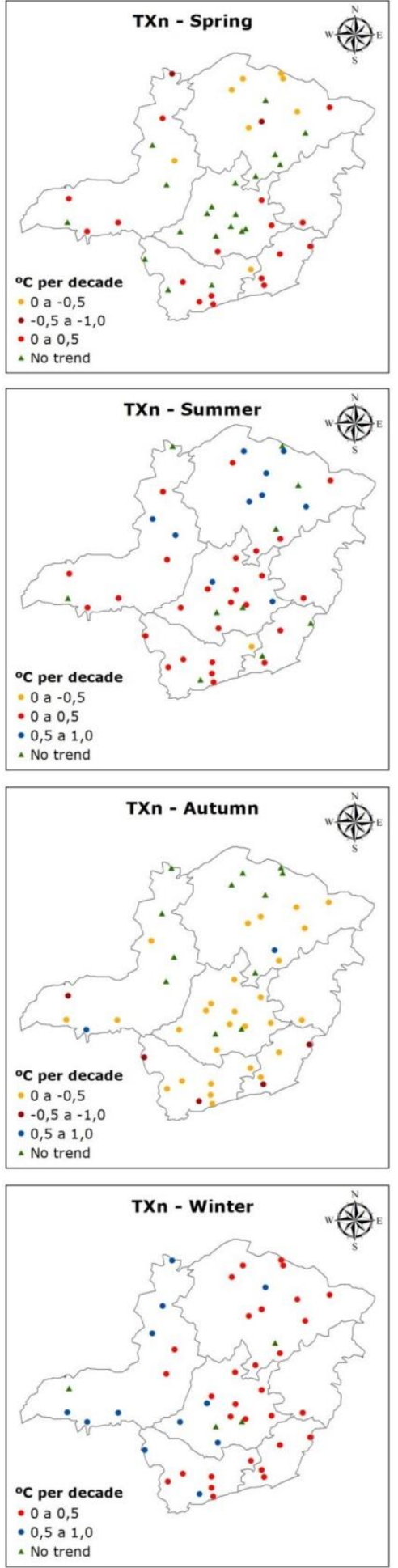

a)

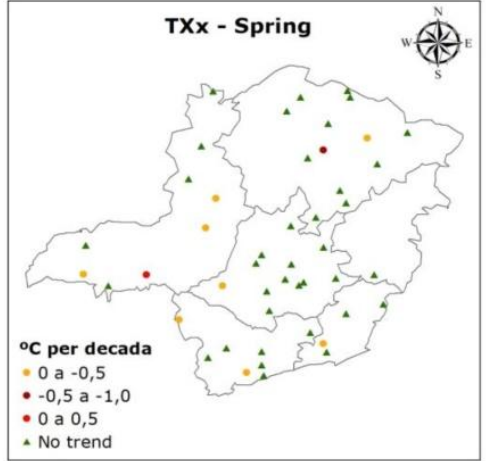

c)

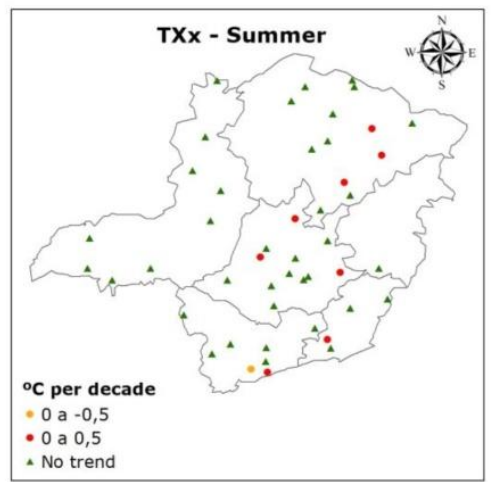

e)

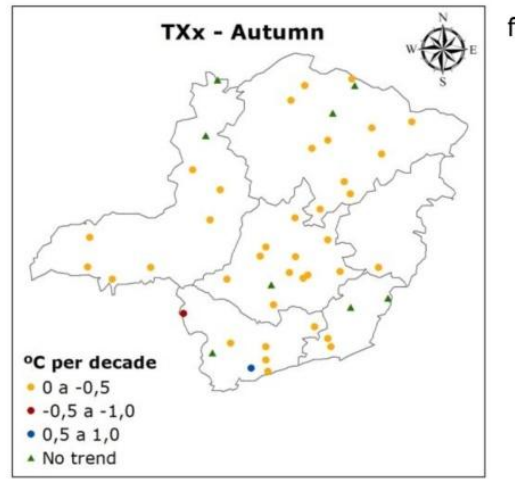

g)

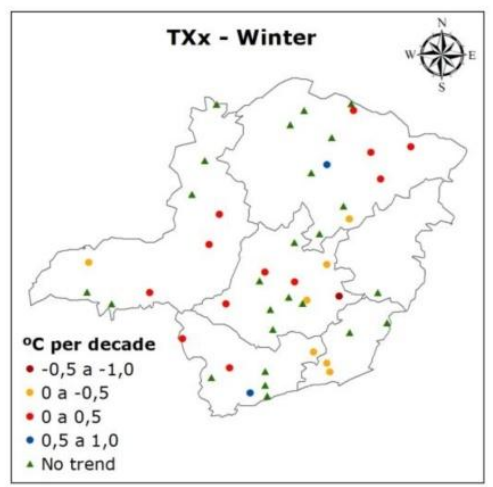

b)

d)

Figure III - Spatial distribution of extreme climatic indices of maximum air temperature trends for Minas Gerais state during Spring $(a, b)$, Summer $(c, d)$, Autumn $(e, f)$ and Winter $(\mathrm{g}, \mathrm{h})$ for the 1961 to 2010 period. 
Neves et al. (2016), studying 28 municipalities in the Paraná state, South Brazil, with maximum and minimum air temperature series, in the period from 1980 to 2009, observed alterations in most of these stations, from reductions, with rates up to $-0.5^{\circ} \mathrm{C}$ per decade, to increases of up to $0.6^{\circ} \mathrm{C}$ per decade. The increases were mainly in the winter and spring and the reductions in autumn. Regarding the maximum temperature, reductions were also observed in autumn and an increase in winter and spring. These results are very similar to those obtained for Minas Gerais in this study, as above presented and discussed. In this same context, Silva et al. (2015) analyzed trends of climatic extremes in 20 meteorological stations also in Paraná state. The results of the related indicators point to a statistically significant warming pattern in most of this state, and those associated with minimum temperatures showed more significant upward trends than the maximum temperature, exactly as observed in the present study.

Similar behaviors for the studies in Minas Gerais and Paraná for temperatures suggest that, on a continental scale, regions occupying ranges of tropical latitude with transition to subtropical bands, demonstrate the possible effects of global warming, especially in the spring and summer seasons. This pattern found relation with the results from climate change simulations for eastern South America, generated by Chou et al. (2014).

Due to the increase associated with minimum extreme temperatures in winter, the South and Southeastern regions of Minas Gerais may present restrictions to crops that demand accumulated hours of cold or even crops that do not show good development under higher temperatures conditions, such as coffee, representing a decline in crop quality and productivity. In this direction, Assad et al. (2004) worked with data from the IPCC (2004) and simulated and evaluated that the impact of the increase in average air temperature of $1^{\circ} \mathrm{C}, 3^{\circ} \mathrm{C}$ and $5.8^{\circ} \mathrm{C}$ until the end of the 21 st century and a $15 \%$ increase in rainfall would affect the potential of Brazilian coffee cultivation, defined by the agroclimatic coffee zoning (Coffea arabica L.), in the states of Goiás, Minas Gerais, São Paulo and Paraná. In Minas Gerais, the increase of $1^{\circ} \mathrm{C}$ in temperature and $15 \%$ increase in rainfall would provide reductions in the necessary irrigation area in the Northwest and Center regions, and consequently, the displacement of the area with productive potential to the South. The authors conclude yet that the total area in the state which is unable to coffee crop cultivation, would be increased from $24.1 \%$ to $43.3 \%$.

On the other hand, it is possible to cultivate alternative crops that previously would not be possible due to the lower temperatures in the South and Southeastern of Minas Gerais, possibly making these regions friendlier towards tropical crops and extending the planting season of some others. In this context, Haddad et al. (2011) suggest that the increase in temperatures in Minas Gerais can promote a shift of economic activity into the South and Center regions, which tends to accentuate the already high regional economic disparity in the State.

In addition to the economic aspect, it is important to highlight the increase in cases of diseases associated with arboviruses, especially dengue, both in the state of Minas Gerais and Paraná, in the last 20 years. Such diseases are known as "neglected" and are typically transmitted by tropical vectors (mosquitoes), which proliferate mainly due to increased temperature and 
humidity. In both states, such events have tripled since the 1990s, and one of the primary factors that has contributed to this current scenario may be the increase in temperatures, especially in the spring. This behavior favors the early development of the transmitters, anticipating their proliferation, which was previously prevalent only between January and March. This aspect has enabled the advance of increasingly frequent epidemics in areas where this type of disease was practically non-existent, as in southern Minas Gerais.

Thus, although Minas Gerais has presented a warming trend in the last 50 years considered low, in comparison with climate model forecasts, the negative consequences of this increase are already present, evidencing the importance of evaluating mitigating actions to lessen them over the medium and long terms according to climate alterations that may still occur in the State.

\section{CONCLUSIONS}

a) The extreme indices related to precipitation (R10mm, R20mm and SDII) did not show significant alterations between 1961 and 2010 in Minas Gerais state;

b) It was evidenced that in the period between 1961 and 2010, there was a significant increase in the values of the TNn, TNx, TXn and TXx indices, especially in the spring, in all regions of Minas Gerais. However, in the autumn, there was a downward trend in all these extreme temperature indices, meaning that this season of the year tended to be cooler in this season of year. Regarding the behavior of these indices, those associated with minimum temperatures produced more impacting results over Minas Gerais, presenting higher rates of alteration.

c) The warmer spring, both in terms of extreme as well as minimum and maximum average temperatures, has had important consequences on the quality of life in Minas Gerais, possibly being one of the factors responsible for the increase of arboviruses, especially dengue, in the recent decades;

d) Winter tended to be warmer and shorter because of the increase in minimum extreme temperatures in this season, as well as a more intensified warming in the spring. This behavior has resulted in a reduction in the occurrence of frost with medium to strong intensities in the South and Southeastern regions of Minas Gerais, especially collaborating with the coffee plantations, but reducing the number of cold hours needed for temperate climate crops typical of these regions.

\section{ACKNOWLEDGEMENTS}

To the Coordenação de Aperfeiçoamento de Pessoal de Nível Superior (CAPES) for providing the grant, enabling this work to be conducted. To INMET for making the database available. 


\section{REFERENCES}

ALEXANDER, L.V.; ZHANG, X; PETERSON, T.C.; CAESAR, J.; GLEASON, B.; KLEIN TANK, A.M.G.; HAYLOCK, M.; COLLINS, D.; TREWIN, B.; RAHIMZADEH, F.; TAGIPOUR, A.; KUMAR, K.R.; REVADEKAR, J.; GRIFFITHS, G.; VINCENT, L.; STEPHENSON, D.B.; BURN, J.; AGUILAR, E.; BRUNET, M.; TAYLOR, M.; NEW, M.; ZHAI, P.; RUSTICUCCI, M.; VAZQUEZ-AGUIRRE, J.L. Global Observed Changes in Daily Climate Extremes of Temperature and Precipitation. Journal of Geophysical Research, 111: D05109, 2006. DOI: 10.1029/2005JD006290

ARAÚJO, F.R.C.D.; SANTOS, C.A.C.S.; NASCIMENTO, F.C.A. Estudo dos índices extremos de temperatura na bacia Hidrográfica do Baixo Rio Colorado, EUA. Revista Brasileira de Meteorologia v.30, p. 29-36, 2015.

ARAUJO, W.S.; BRITO, J.I.B. Índices de tendências de mudanças climáticas para os Estados da Bahia e Sergipe por meio de índices pluviométricos diários e sua relação com TSM do Pacífico e Atlântico. Revista Brasileira de Meteorologia, v. 26, p.541-554, 2011.

ASSAD, E.D., PINTO, H.S., JUNIOR, JZ, ÁVILA, A.M.H. Impacto das mudanças climáticas no zoneamento agroclimático do café no Brasil. Pesquisa Agropecuária Brasileira, v. 39, p.1057-1064, 2004.

ASSAD, E.D.; PINTO, H.S. Aquecimento global e a nova geografia da produção agrícola no Brasil. 1. ed. Brasília: Embaixada Britânica, v. 1, 82p. 2008.

ÁVILA, L.F.; MELLO, C.R.; YANAGI, S.N.M.; NETO, O.B.S. Tendências de temperaturas mínimas e máximas do ar no Estado de Minas Gerais. Pesquisa Agropecuária Brasileira, v. 49, p.247-256, 2014. DOI: 10.1590/S0100$204 \times 2014000400002$.

BARROS, V.R.; DOYLE, M.E.; CAMILLONI, I,A. Precipitation trends in southeastern South America: relationship with ENSO phases and with low-level circulation. Theoretical and Applied Climatology, V. 93: p.19-33, 2008.

BLAIN, G.C. Séries anuais de temperatura máxima média do ar no Estado de São Paulo: variações e tendências climáticas. Revista Brasileira de Meteorologia, v.25, n.1, $114-124,2010$

BROWN, P. J.; BRADLEY, R. S.; KEIMIG, F. T. Changes in extreme climate indices for the Northeastern United States, 1870-2005. American Meteorological Society, v. 23, p. 6555-6572, 2010. DOI:10.1175/2010JCLI3363.1

CORDEIRO, A. P. A.; Berlato, M. A.; FONTANA, D. C.; AlVES, R. C. M. Tendências climáticas das temperaturas do ar no Estado do Rio Grande do Sul, Sul do Brasil. Revista Brasileira de Geografia Física. v.09, n.03. 868-880, 2016.

DANTAS, L. G.; SANTOS, C. A. C.; OLINDA, R. A. Tendências anuais e sazonais nos extremos de temperatura do ar e precipitação em Campina Grande - PB. Revista Brasileira de Meteorologia, v. 30, n. 4, 423 - 434, 2015. DOI: 10.1590/0102-778620130088.

DONAT, M. G., and COAUTHORS. Updated analyses of temperature and precipitation extreme indices since the beginning of the twentieth century: The HadEX2 dataset. J. Geophys. Res., 118, 2098-2118, 2012.

DRUMMOND, G. M.; MARTINS, C. S.; MACHADO, A. B. M.; SEBAIO, F. A.; ANTONINI, Y. Biodiversidade em Minas Gerais. 2. ed. Belo Horizonte: Fundação 
Biodiversitas, 2005.2 Disponível em: <http://www.biodiversitas.org.br/atlas/flora.pdf>. Acesso em: 14 nov. 2016.

HADDAD, E. A.; DOMINGUES, E. P.; FERES, J. G. Avaliação de impactos de mudanças climáticas sobre a economia mineira: relatório resumo. Belo Horizonte: Fundação Estadual do Meio Ambiente, 46p. 2011.

IPCC, 2007. Climate change 2007: the physical science basis. In: Solomon, S., Qin, D., Manning, M., Chen, Z., Marquis, M., Averyt, K.B., Tignor, M., Miller, H.L. (Eds.), Contribution of Working Group I to the Fourth Assessment Report of the Intergovernmental Panel on Climate Change. Cambridge University Press, Cambridge, United Kingdom and New York, NY, USA, 996 p.

IPCC, 2013: Climate Change 2013: The Physical Science Basis. Contribution of Working Group I to the Fifth Assessment Report of the Intergovernmental Panel on Climate Change [Stocker, T.F., D. Qin, G.-K. Plattner, M. Tignor, S.K. Allen, J. Boschung, A. Nauels, Y. Xia, V. Bex and P.M. Midgley (eds.)]. Cambridge University Press, Cambridge, United Kingdom and New York, NY, USA, 1535 p.

IPCC, 2014: Climate Change 2014: Mitigation of Climate Change. Contribution of Working Group III to the Fifth Assessment Report of the Intergovernmental Panel on Climate Change [Edenhofer, O., R. Pichs-Madruga, Y. Sokona, E. Farahani, S. Kadner, K. Seyboth, A. Adler, I. Baum, S. Brunner, P. Eickemeier, B. Kriemann, J. Savolainen, S. Schlömer, C. von Stechow, T. Zwickel and J.C. Minx (eds.)]. Cambridge University Press, Cambridge, United Kingdom and New York, NY, USA.

KENDALL, M.G.. Rank Correlation Methods. Charles Griffin, London. 1975

KRUGER, A. C. and SEKELE, S. S. Trends in extreme temperature indices in South Africa:1962-2009. International Journal of Climatology, v. 33: 661-676, 2013. DOI: $10.1002 /$ joc. 3455

LOBELL, D.B.; SXHLENKER, W.; ROBERTS, J. C. Climate trends and global crop production since 1980. Science, 29: 616-620, 2011.

MARCOTT, S. A.; SHAKUN, J. D.; CLARK, P. U.; MIX, A. C. A reconstruction of Regional and Global Temperature for the Past 11.300 Years. Science, v. 339, p. 1198 - 1201, 2013. DOI: 10.1126/science. 1228026

NATIVIDADE, U. A.; GARCIA, S. R.; TORRES, R. R. Tendência dos Índices de Extremos Climáticos Observados e Projetados no Estado de Minas Gerais. Revista Brasileira de Meteorologia, v. 32, n. 4, p. 600-614, 2017. DOI: http://dx.doi.org/10.1590/0102-7786324008

MANN, H.B. Nonparametric tests against trend. Econometrika,13, 245-259. 1945.

MARTINEZ, C. J.; MALESKI, J. J.; MILLER, M. F. Trends in precipitation and temperature in Florida, USA. Journal of Hydrology, v. 452-453, p. 259-281, 2012. DOI:10.1016/j.jhydrol.2012.05.066

MINUZZI, R. B.; CARAMORI, P. H. BORROZINO, E. Tendências na variabilidade climática sazonal e anual das temperaturas máxima e mínima do ar no Estado do Paraná. Bragantia, Campinas, v. 70, n. 2, p.471-479, 2011

MINUZZI, R. B.; VIANELLO, R. L.; SEDIYAMA, G. C. Oscilações climáticas em Minas Gerais. Revista Brasileira de Meteorologia, v.25, n.2, 227 - 236, 2010. 
NEETI, N; EASTMAN, J.R. A Contextual Mann-Kendall Approach for the Assessment of Trend Significance in Image Time Series. Transactions in GIS, 15(5): 599-611. 2011.

NEVES, G. L.; VIRGENS FILHO, J. S.; LEITE, M. L.; SANTOS, E. N. Trend of air temperature in the State of Paraná, Brazil. Revista Brasileira de Climatologia. V. 18 , p. 180 - 193, 2016.

NÓBREGA, J. N.; SANTOS, C. A. C.; GOMES, O. M.;BEZERRA, B. G.; BRITO, J. I. B. Eventos extremos de precipitação nas mesorregiões da Paraíba e suas relações com a TSM dos Oceanos Tropicais. Revista Brasileira de Meteorologia, v.29, n.2, 197 - 208, 2014.

NUNES, A. A.; PINTO, J. A.; BAPTISTA, M. B. Detection of trends for extreme events of precipitation in the Metropolitan Region of Belo Horizonte through statistical methods. Revista Brasileira de Recursos Hídricos, Porto Alegre, v. 23, e9, 2018.

OBREGON G.; MARENGO, J. A. (2007), Caracterização do clima do Século XX no Brasil: Tendências de chuvas e temperaturas médias e extremas. Relatório 2, Ministério do Meio Ambiente - MMA, Secretaria de Biodiversidade E Florestas SBF, Diretoria de Conservação da Biodiversidade - DCBio Mudanças Climáticas Globais e Efeitos sobre a Biodiversidade - Sub projeto: Caracterização do clima atual e definição das alterações climáticas para o território brasileiro ao longo do Século XXI. Brasília.

PENEREIRO, J. C.; MESCHIATTI, M. C. VARIABILIDADES E TENDÊNCIAS CLIMÁTICAS NOS MÁXIMOS DO INVERNO E VERÃO NO BRASIL. Revista Brasileira de Climatologia. v. 21, p. 378 - 400, 2017.

PINHEIRO, A.; GRACIANO, R. L. G.; SEVERO, D. L. Tendências das séries temporais de precipitação da região Sul do Brasil. Revista Brasileira de Meteorologia, v.28, n.3, 281 - 290, 2013.

POWELL, E.; KEIM, B. D. Trends in Daily Trends in Daily Temperature and Precipitation Extremes for the Southeastern United States: 1948-2012. Journal of Climate, v. 28, p. 1592- 1612, 2015. DOI: 10.1175/JCLI-D-14-00410.1

SÁ JUNIOR, A.; CARVALHO, L. G.; SILVA, F. F.; ALVES, M. C. Application of the Köppen classification for climatic zoning in the state of Minas Gerais, Brazil. Theoretical and Applied Climatology. v. 108, p.1-7, 2012. DOI: 10.1007/s00704-011-0507-8

SALVIANO, M. F.; GROPPO, J.D.; PELLEGRINO, G. Q. Análise de Tendências em Dados de Precipitação e Temperatura no Brasil. Revista Brasileira de Meteorologia, v. 31, n. 1, 64-73, 2016. DOI: 10.1590/0102-778620150003

SANTOS, C. A. C.; MELO, M. M. M. S.; BRITO, J. I. B. Tendências de Índices de Extremos Climáticos para o Estado do Amazonas e suas Relações com a TSM dos Oceanos Tropicais. Revista Brasileira de Meteorologia, v. 31, n. 1, p. 1-10, 2016. DOI: http://dx.doi.org/10.1590/0102-778620130001

SANTOS, C. A. C. Recent changes in temperature and precipitation extremes in an ecological reserve in Federal District, Brazil. Revista Brasileira de Meteorologia, v.29, n.1, 13 - 20, 2014 
SANTOS, C. A. C.; BRITO, J. I. B.; SANTOS, E. G.; RAO,. T; V. R.; SILVA, V. P. R. Temporal variability of extreme temperature índices in Utah during the past few decades. Revista Brasileira de Meteorologia, v.28, n.4, 364 - 372, 2013.

SANTOS, C. A. C.; SATYAMURTY, P. SANTOS, E. M. Tendências de índices de extremos climáticos para a região de Manaus-AM. Acta Amazônica. vol. 42(3) p. $329-336,2012$.

SHARNA, D.; BABEL, M. S. Trends in extreme rainfall and temperature índices in the western Thailand. International Journal of Climatology, v. 34: 2393-2407, 2014. DOI: $10.1002 /$ joc.3846

SILVA, G. B.; AZEVEDO, P. V. ÍNDICES DE TENDÊNCIAS DE MUDANÇAS CLIMÁTICAS NO ESTADO DA BAHIA. Engenharia Ambiental - Espírito Santo do Pinhal, v. 5, n. 3, p. 141-151, set/dez 2008.

SILVA, W. L.; DERECZYNSKI, C.; CHANG, M.; FREITAS, M.; MACHADO, B. J.; TRISTÃO, L.; RUGGERI, J. Tendências observadas em indicadores de extremos climáticos de temperatura e precipitação no Estado do Paraná. Revista Brasileira de Meteorologia, v. 30, n. 2, 181-194, 2015.

STEPHENSON, T. S. et al. Changes in extreme temperature and precipitation in the Caribbean region, 1961-2010. International Journal of Climatology, v. 34, p. 2957-2971, 2014. DOI: 10.1002/joc.3889

OMONDI, P. A., et al. Changes in temperature and precipitation extremes over the Greater Horn of Africa region from 1961 to 2010. International Journal of Climatology, v. 34, p. 1262-1277, 2014. DOI: 10.1002/joc.3763

VARGAS, W. M.; NAUMANN, G. Impacts of climatic change and low frequency variability in reference series on daily maximum and minimum temperature in southern South America. Reg Environ Change, v. 8, p. 45-57, 2008. DOI: $10.1007 / \mathrm{s} 10113-007-0041-5$

WILKS, D.S. Statistical methods in the atmospheric sciences. San Diego: Academic Press, 1995. 467p.

YUE, S; PILON, P; CAVADIAS, G. Power of the Mann-Kendall and Spearman's rho tests for detecting monotonic trends in hydrological series. Journal of Hydrology 259:254-271. 2002.

ZHANG, W; YAN, Y; ZHENG, J; L.I.L.; DONG, X; CAI, H. Temporal and spatial variability of annual extreme water level in the Pearl River Delta region, China. Global and Planetary Change 69:35-47. 2009 